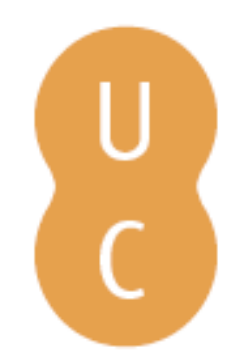

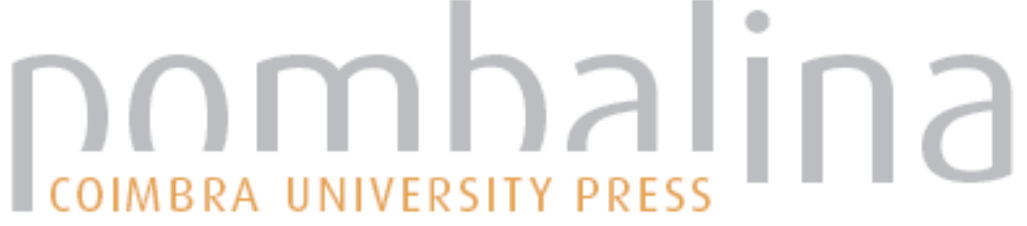

\section{Lethal inhalation of Popper}

Autor(es): $\quad$ Papi, L.; Giusiani, M.; Marra, D.; Chericoni, S.

Publicado por: Imprensa da Universidade de Coimbra

URL

persistente: URI:http://hdl.handle.net/10316.2/31734

DOI: $\quad$ DOI:http://dx.doi.org/10.14195/978-989-26-0173-1_72

Accessed : $\quad$ 26-Apr-2023 10:55:44

A navegação consulta e descarregamento dos títulos inseridos nas Bibliotecas Digitais UC Digitalis, UC Pombalina e UC Impactum, pressupõem a aceitação plena e sem reservas dos Termos e Condições de Uso destas Bibliotecas Digitais, disponíveis em https://digitalis.uc.pt/pt-pt/termos.

Conforme exposto nos referidos Termos e Condições de Uso, o descarregamento de títulos de acesso restrito requer uma licença válida de autorização devendo o utilizador aceder ao(s) documento(s) a partir de um endereço de IP da instituição detentora da supramencionada licença.

Ao utilizador é apenas permitido o descarregamento para uso pessoal, pelo que o emprego do(s) título(s) descarregado(s) para outro fim, designadamente comercial, carece de autorização do respetivo autor ou editor da obra.

Na medida em que todas as obras da UC Digitalis se encontram protegidas pelo Código do Direito de Autor e Direitos Conexos e demais legislação aplicável, toda a cópia, parcial ou total, deste documento, nos casos em que é legalmente admitida, deverá conter ou fazer-se acompanhar por este aviso. 


\section{Duarte Nuno Vieira Anthony Busuttil \\ Denis Cusack • Philip Beth}
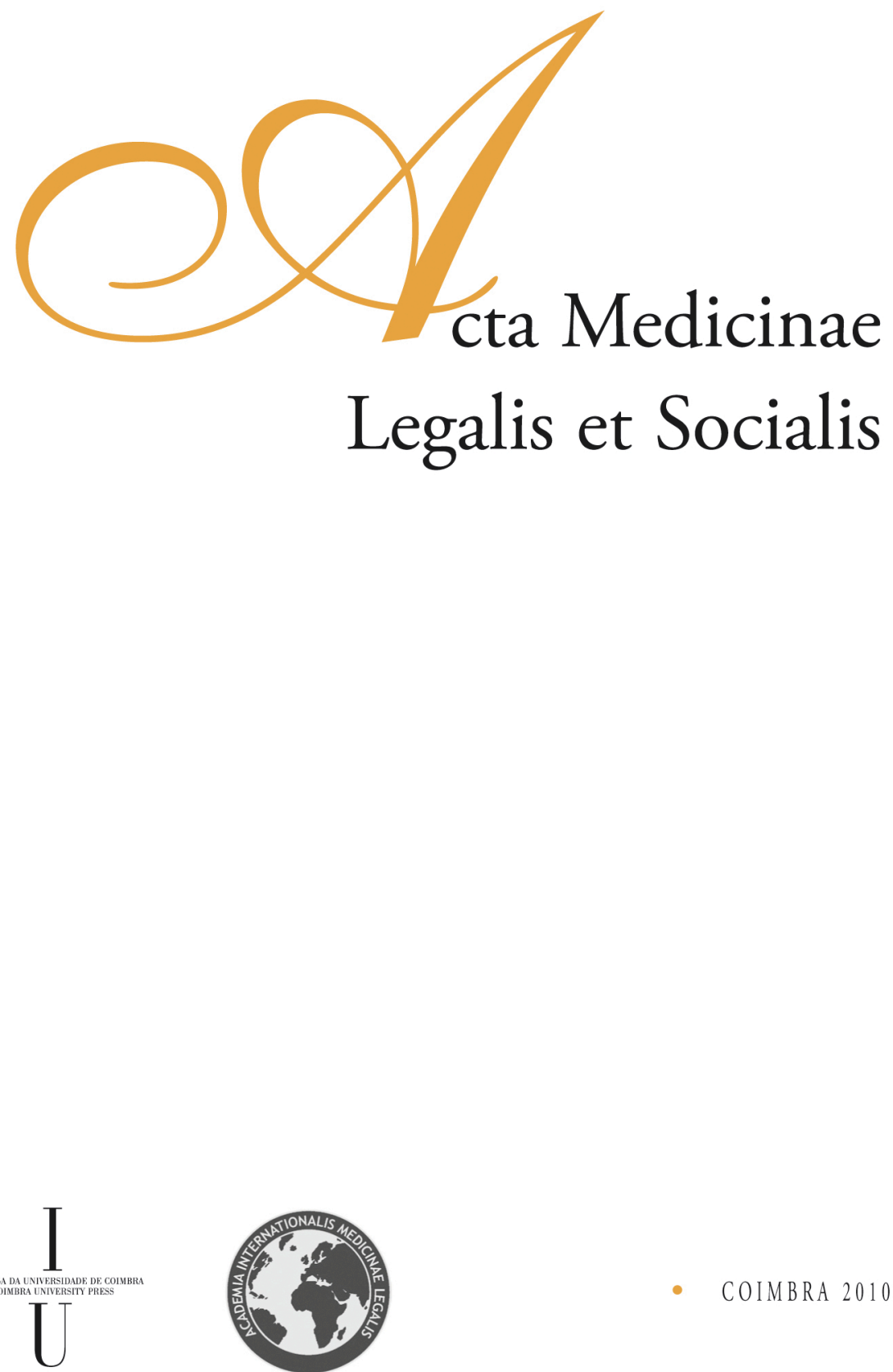


\author{
L. Papi, M. Giusiani, D. Marra, S. Chericoni \\ Department of Legal Medicine, University of Pisa, Italy
}

\title{
LETHAL INHALATION OF POPPER
}

\begin{abstract}
We present a case about an unexpected death occurred during inhalation of Popper, a recreational drug constituted by alkyl nitrates, which is generally considered safe for life, despite its activity on cardiovascular system. Fatal inhalation of nitrates are extremely rare in world literature; the dangerousness from nitrate are primarily related to the synthesis of methaemoglobin, the oxidative form of haemoglobin, which cannot carry oxygen causing hypoxia. In some instances death from nitrates can derivate from lethal arrhythmias induced by a sensibilisation of myocardium to cathecolamine. In our case toxicological analysis were hampered by advanced putrefaction, but nevertheless it was possible to asses in biological samples the presence of Butyraldehyde dibutylacetal, a molecule originated during the chemical synthesis of nitrates but more stable, that confirmed the assumption of Popper just before the death.
\end{abstract}

\section{Introduction}

Popper is a recreational drug constituted by various alkyl nitrates, as amylnitrite, butyl nitrite, isopropyl nitrite and isobutyl nitrite, that has begun gradually to widespread since 60's years. Nowadays it is usually sold in sexy-shops (somewhere as a room deodorizer) in little plastic bottles or imbued in cotton or other adsorbent materials. Popper, (the name derivates from the period when the drug was sold in small glass tubes, covered with fishnet, that made a popping noise when broken to open and inhale) is known as a recreational drug, traditionally abused in male homosexuals activity (1) because of the induction of a vigorous excitant effect associated to anal muscle relax and anesthetization.

It is assumed by inhalation and the effects begin within few seconds and last for a very short period (from 30 seconds to 2 minutes), and the effects consist in relaxation of smooth muscle surrounding the blood vessels resulting in an immediate increase in heart rate and blood flow throughout the body, producing a sensation of heat, euphoria and excitement; at the same time, the relaxation of the sphincters of the anus and vagina make penetration easier so it's commonly said that poppers can enhance and prolong orgasm. 


\section{Case report}

A 48-years old man, who was working as a musician on a cruise-ship, was found dead inside his cab, after he had been seen alive 36 hours before the discovery of the body, when he entered into his cabin for the last time, as recorded by the magnetic-key.

Some days before he underwent a medical control to receive topical cream to treat a rush around his mouth, which he alleged as a reaction to dental surgery. No significant pathology was noticed in his clinical folder.

The body was found in advanced state of decomposition, with severe swelling of face and limbs. He was sitting on a chair, lining on his right side, dressing only a t-shirt and a pair of socks (Fig. 1). He was in front on desk where a DVD-monitor was showing an hardcore movie of sadomasochist genre. The man had a mask on his face (Fig. 2), with a wad of cotton inside emanating a sweetish smell. On the desk, near the body, there were three little bottles, whose labels was that of a room odorizer named "Jungle Juice". In the refrigerator there were others equal and more bottles with the label "Rush" (Fig. 3). In the cab there were also Viagra package and some tablets of smart-drug, containing caffeine and other natural components. The room has been locked from inside and the cracks of the door and air conditioned-grid were sealed with adhesive taped (Fig. 4); a friend referred that the deceased alleged he was used to did so to prevent noise disturbing him while he was asleep.

Autopsy findings just consisted in severe coronarosclerosis of the descendant anterior coronary artery, with histological evidence of mild miocardiosclerosis, pulmonary congestion and hepatosteatosis. A thorough inspection of the nose, lips and neck didn't reveal any traumatic injuries, although we must consider that putrefaction could have made little abrasion or bruise impossible to be noticed.

\section{Toxicological analysis}

Toxicological tests, performed with Thermo Fisher Scientific (GC) coupled to DSQII (MS), revealed that the liquid inside the bottles contained isobutyl-nitrite.

Although the research of this substance in biological samples resulted negative because of the extreme volatility and the effects of putrefaction, that affected also the research of methaemoglobin for the endogenous production of this molecule during blood decomposition, the GC/MS showed the presence of an organic compound in Rush, named Butyraldehyde dibutylacetal, that was discovered also in sample of tissue from cadaver (blood, hair, lung, brain, liver and kidney) and in the wad of cotton found inside the mask. This molecule is produced during chemical syinthesis of nitrates and it was possible to found it in biological samples because of it's more stable than vapours of nitrate.

\section{Discussion and conclusion}

Isobutyl-nitrate and amyl-nitrate are the active molecules of Popper, whose assumption is still increasing, especially in male homosexuals contest (2.) Once exposure to substance has occurred, usually by inhalation, the effects are rapid and brief, so multiple intakes during sexual activity could be required. 
The nitrate is rapidly absorbed and vasodilatation can result in palpitation, skin flushing, hypoxia and dizziness. Headaches, nausea and syncope are also described.

Toxic effects arise from production of methaemoglobin, the oxidative product of haemoglobin, that is incapable to carry oxygen, determining generalized hypoxia.

Fatal cases related to assumption of Popper are extremely rare, especially by inhalation intake. Bradberry et al. (3) reported a case of fatal methaemoglobinemia due to inhalation of Popper, while a few other reports of clinically significant (but not lethal) methaemoglobinemia, related to the assumption of nitrates, are described $(4,5,6)$. Besides, isolated lethal cases has been documented when alkylnitrites have been taken orally $(7,8)$.

For these reasons, in suspect of Popper's assumption, methaemoglobinemia determination is necessary, in addition to the dosage of nitrite and nitrate in blood and stomach contents.

Some Authors suggest that frequently death can occur suddenly for arrhythmias, as a result of myocardial sensibilisation to catecholamine induced by inhalants, consisting in the so-called Sudden Sniffing Death (SSD), firstly described by Bass in 1970 (9).

Referring to our case, all the evidence from technical survey and autopsy were strongly indicative of an assumption of Popper with exclusion of a possible involvement of other persons in causing the death. Although toxicological analysis aimed to the research of nitrites and methaemoglobin have been not useful by putrefaction, laboratory investigation showed the presence in biological sample (blood, hair, lung, brain, liver and kidney) and in the cotton wad found inside the mask, of Butyraldehyde dibutylacetal, a molecule produced in chemical synthesis of nitrates but not as volatile, offering the evidence of intra-vitam assumption of Popper. From the discovery of nitrate inhalation, there are no doubts that perioral skin rush and abrasion were due to multiple contacts with irritant nitrate vapours and that the hermetic sealing of doors and grid was performed to avoid vapours getting out from the cab and being perceived by staff members of the ship.

\section{References}

BASS M. Sudden sniffing death. JAMA 1970;212:2075-9.

BRADBERRY SM et al, Fatal methemoglobinemia due to inhalation of isobutyl nitrite. J Toxicol Clin Toxicol 1994;32:179-184.

GUSS DA ET AL, Clinically significant methemoglobinemia from inhalation of isobutyl nitrite. Am J Emerg Med 1985;3:46-7.

HORNE MK AT AL, Methemoglobinemia from sniffing butyl nitrite. Ann Intern Med 1979;91:417-8.

LIN CH ET AL, Near-fatal methemoglobinemia after recreational inhalation of amyl nitrite aerosolized with a compressed gas blower. J Formos Med Assoc 2005;104:856-9.

MACHABERT R ET AL., Methaemoglobinaemia due to amyl nitrite inhalation: a case report. Hum Exp Toxicol 1994;13:313-4.

SAITO T ET AL, A case of fatal methemoglobinemia of unknown origin but presumably due to ingestion of nitrate. Int J Leg Med 2000;113:165-7.

SARVESVARAN ER ET AL., Amyl nitrite related deaths. Med Sci Law 1992;32:267-9.

WAUGH M, Amylnitrite as a sexual stimulant. Br Med J 1979; 25:499. 